\title{
Changes in community structure in temperate marine reserves
}

\author{
Russell C. Babcock*, Shane Kelly, Nick T. Shears, Jarrod W. Walker, Trevor J. Willis
}

Leigh Marine Laboratory, University of Auckland, PO Box 349, Warkworth, New Zealand

\begin{abstract}
No-take' marine reserves provide a valuable tool for managing marine resources as well as for providing relatively undisturbed habitat with which to assess modifications to ecosystems. We studied 2 marine reserves in northeastern New Zealand, the Leigh Marine Reserve (established 1975) and Tawharanui Marine Park (established 1982) in order to assess whether changes in protected predator populations had resulted in other indirect changes to grazers and consequently to algal abundance. Estimates of abundance of the most common demersal predatory fish Pagrus auratus indicated that adults of this species (i.e. large enough to prey upon urchins) were at least 5.75 and 8.70 times more abundant inside reserves than in adjacent unprotected areas. Overall, $P$. auratus were also much larger inside reserves with mean total lengths of $316 \mathrm{~mm}$ compared with $186 \mathrm{~mm}$ in fished areas. The spiny lobster Jasus edwardsii displayed similar trends, and was approximately 1.6 to 3.7 times more abundant inside the reserves than outside. Lobsters within the reserves had a mean carapace length of $109.9 \mathrm{~mm}$, compared with $93.5 \mathrm{~mm}$ outside the reserves. In one of the reserves, densities of the sea urchin Evechinus chloroticus had declined from 4.9 to $1.4 \mathrm{~m}^{-2}$ since 1978 in areas formerly dominated by it. Consequently, kelp forests were more extensive in 1998 than they were at the time of reserve creation. Urchin-dominated barrens occupied only $14 \%$ of available reef substratum in reserves as opposed to $40 \%$ in unprotected areas. These changes in community structure, which have persisted since at least 1994, demonstrate not only higher trophic complexity than anticipated in Australasian ecosystems but also increased primary and secondary productivity in marine reserves as a consequence of protection. Trends inside reserves indicate large-scale reduction of benthic primary production as an indirect result of fishing activity in unprotected areas.
\end{abstract}

KEY WORDS: Marine reserves - Habitat change - Trophic structure - Fishing effects - Urchins - Kelp Fish. Spiny lobsters

\section{INTRODUCTION}

'No-take' marine reserves are increasingly being promoted as a means of managing coastal resources. This is true not only with respect to restoring or protecting exploited species, but also as a way of protecting marine ecosystems from the indirect effects of fishing (Agardy 1994, Botsford et al. 1997, Allison et al. 1998, Pauly et al. 1998). It has been demonstrated that exploited species are more abundant within protected areas than outside of them (Bennett \& Attwood 1991, Rakitin \& Kramer 1996, Russ \& Alcala 1996, Millar \& Willis 1999), but much less is known of the

•E-mail: r.babcock@auckland.ac.nz indirect response by marine ecosystems to renewed abundance of these species. Algal succession on tropical coral reefs has been shown to vary according to types of grazing pressure in marine reserves, with more diverse and abundant algal turfs in marine reserves primarily grazed by herbivorous fish (McClanahan 1997). Intertidal communities in Chile have responded to protection from harvesting with marked structural changes (Duran \& Castilla 1989). In the absence of the predatory gastropod Concholepas choncholepas, mussels dominated the intertidal zone, but inside a reserve, predation of mussels by $C$. choncholepas allowed quite a different community dominated by barnacles and algae to develop. Similar information from subtidal temperate systems is sparse, but what little is known about indirect responses of 
ecosystems to predator increases has had a considerable influence on marine ecological theory. Perhaps the best known example of this is the interaction between sea otters, sea urchins and kelp (Estes \& Palmisano 1974, Duggins 1980).

The importance of the 3-tiered sea otter-urchin-kelp trophic cascade was demonstrated after sea otters were all but wiped out by harvesting for their fur, allowing their prey, sea urchins, to overgraze kelps and dominate many benthic ecosystems. After the repopulation of areas by otters, kelp and its associated communities became much more abundant. Recent declines in otter populations in the Aleutian Islands have confirmed their importance in that ecosystem (Estes et al. 1998). Similar processes, involving fish predators, are thought to be present in Mediterranean benthic communities (Sala et al. 1998) although other physical and ecological factors are also likely to be important. Trophic cascades involving predation by fish and lobsters on urchins have been proposed to exist in North Atlantic subtidal ecosystems, but remain controversial (Chapman \& Johnson 1990, Elner \& Vadas 1990). Furthermore, it has been suggested that in southern hemisphere subtidal habitats a much simpler 2-tiered trophic cascade exists (Steinberg et al. 1995), in which predation on urchins is not intense enough to control grazer populations (Andrew \& Choat 1982, Andrew \& MacDiarmid 1991).

Much of the early subtidal marine ecological work in northeastern New Zealand has been carried out in the Leigh Marine Reserve (Choat \& Schiel 1982, Schiel 1982, Creese \& Jeffs 1993). Surveys at the time of reserve establishment described 3 major habitat types. These were the shallow ( 0 to $4 \mathrm{~m}$ ) 'mixed algae' zone, urchin barrens or 'rock-flats' dominated by crustose coralline algae and maintained by the common sea urchin Evechinus chloroticus ( 4 to $10 \mathrm{~m}$ ), and deeper $(10$ to $20+m)$ kelp forests dominated by the laminarian Ecklonia radiata (Schiel 1990).

We asked the following questions: (1) Has the abundance of predators in protected areas increased? (2) Has the abundance of invertebrate grazers decreased? (3) Are changes in grazer abundance caused by predator abundance? (4) Has the abundance of macroalgae increased? (5) Are changes in the abundance of macroalgae caused by changes in grazer abundance? Increased density and size of predators in areas protected from fishing should result in high levels of predation on urchins, and reduced grazing should result in more extensive and denser kelp populations (Schiel 1990). In addition to demonstrating indirect ecological effects as a result of marine reserve status, the presence of such effects would represent evidence for the existence of a 3-tiered trophic cascade in an Australasian temperate reef ecosystem.

\section{METHODS}

Study areas. The study areas were the 2 oldest marine reserves in New Zealand (Fig. 1), the Cape Rodney to Okakari Point Marine Reserve (hereafter the Leigh Marine Reserve, 549.16 ha, established 1975) and Tawharanui Marine Park $15 \mathrm{~km}$ to the south (350 ha, established 1982). Non-reserve reference sites were located on similar areas of coast adjacent to the reserves. Sampling effort was spread evenly across both reserve and non-reserve areas by dividing them into a number of sites and then sampling haphazardly within them. This was done to avoid biases that might be associated with human activities in the Leigh marine reserve (e.g. fish feeding, cf. Cole 1994). The fact that fish feeding is not common at Tawharanui further reduces the chance of any such biases affecting the result. Abundances of predators such as demersal fish (primarily the sparid snapper Pagrus auratus) and spiny lobster Jasus edwardsii, and differences in benthic community structure were compared between reserve and non-reserve areas of coast. Snapper and the spiny lobster are heavily targeted by commercial and recreational line and trap fishing; however the New Zealand urchin Evechinus chloroticus is not harvested in significant numbers in this region. Populations of algae and echinoid grazers at Leigh in 1994 and 1996 were also compared with data collected in 1977-78, shortly after the area was protected.

Fish abundance. Estimates of predatory fish abundance and size were made during October and November 1997 using remotely deployed baited video stations. A vertically oriented video camera was mounted over an enclosed bait consisting of 4 whole pilchards Sardinops neopilchardus with 1 additional pilchard tied externally to the bait container. The stand was deployed on sandy substratum adjacent to reef areas at depths of 16 to $24 \mathrm{~m}$. Fish responding to the bait were filmed during $30 \mathrm{~min}$ deployments. The maximum number of fish observed during each deployment was determined by viewing the video recording, and this value was then used as an index of abundance (Willis et al. unpubl.). The fish present in the field of view at the time of maximum abundance were measured by calibrating their images using marks on the video frame. This method provided estimates of total length. The accuracy of length estimates was assessed at $\pm<20 \mathrm{~mm}$ using plastic model fish of known sizes, deployed under the video stand in situ. Four replicate deployments were made in each of 12 sites (each representing approximately $500 \mathrm{~m}$ of coastline) at Leigh and 6 sites at Tawharanui, a total of 72 deployments or $36 \mathrm{~h}$ of video. There were equal numbers of reserve and non-reserve sites at both areas. Gut content data were obtained for fish from the Leigh Marine Reserve 
that suffered mortality incidental to a separate concurrent project (Millar \& Willis 1999).

Spiny lobster abundance. Lobster surveys were conducted at 2 sites within and 2 sites outside each of the reserves. Sites at Leigh and Little Barrier Island were sampled in April, and at Tawharanui and Kawau Islands in October 1995 (Fig. 1). At each site 5 haphazardly placed $50 \times 10 \mathrm{~m}$ transects were surveyed, giving a total of 80 transects covering 4 ha of sea floor. The choice of this transect size was made based on the study by MacDiarmid (1991). He compared the precision of 3 different sized transects; $10 \mathrm{~m} \times 10 \mathrm{~m}, 25 \mathrm{~m} \times$ $10 \mathrm{~m}$ and $50 \mathrm{~m} \times 10 \mathrm{~m}$, in estimating lobster abundance within the Leigh Marine Reserve and found it to be similar in all cases. The larger transect size used was therefore selected to reduce the likelihood of obtaining zero counts in low abundance areas. Two depths $(<10$ and 10 to $25 \mathrm{~m}$ ) were sampled at each site to allow for seasonal changes in the depth distribution of lobsters (MacDiarmid 1991). Sampling was limited to suitable lobster habitat such as broken boulder areas and/or fractured reef (MacDiarmid 1991). All sites were dominated by laminarian and fucalean kelp forests and urchin Evechinus chloroticus zones at shallower depths.

Within each transect the size of every lobster was recorded. A visual size estimation method was used (MacDiarmid 1991), with divers estimating carapace length (CL) to within $5 \mathrm{~mm}$ without capturing or handling individual lobsters. This level of accuracy was achieved through a series of calibration dives where the size of individual lobsters was first estimated by each censor, after which each lobster was caught by hand and measured with vernier calipers to obtain a true length measurement.

Algal abundance. To test whether urchindominated rock-flats (where kelp had been removed by grazing) were less extensive inside protected areas we conducted a series of measurements on 65 transects at 21 sites in and around the 2 reserves in December 1997. The sites used were the same as those for the estimates of fish abundance and an additional 3 transects were laid at Kawau Island (Fig. 1), $2 \mathrm{~km}$ south of Tawharanui. Transects were $1 \mathrm{~m}$ wide and perpendicular to the shore, extending from 0 to $10 \mathrm{~m}$ below chart datum. Three to 4 transects, marked by a weighted line, were located haphazardly within sampling sites. Habitat type under the transect was classified by visual estimate at $1 \mathrm{~m}$ intervals as either shallow mixed fucoid, urchin-dominated rock-flats, kelp forest, articulated coralline turf flat, bare rock or sand. Depth was also recorded. Visual habitat classifications were made on the following basis; kelp forest: $>3$ adult phaeophytes $\mathrm{m}^{-2}$, e.g. Ecklonia radiata or Carpophyllum flexuosum; rock-flats: $>50 \%$ cover of crustose coralline algae and $<3$ adult phaeophytes $\mathrm{m}^{-2}$; shallow mixed fucoid zone: $>20 \%$ algal cover or $>3$ adult phaeophytes $\mathrm{m}^{-2}$ at depths less than $4 \mathrm{~m}$; turf flats: $>50 \%$ cover of turf-forming red or green algae with large phaeophytes $<3 \mathrm{~m}^{-2}$; bare rock: $>50 \%$ of surfaces devoid of any algae. Data were analysed as the proportions of each habitat over the entire transect.

Temporal change in the density of kelp and urchins in the Leigh Marine Reserve. Measurements of the abundance and size of kelp and urchins made in prescribed areas of the Leigh reserve in 1977-78 ('permanent quadrats' Ayling 1978) provided a direct basis for assessing temporal change. These data were obtained in a range of habitat types using haphazard $1 \mathrm{~m}^{2}$

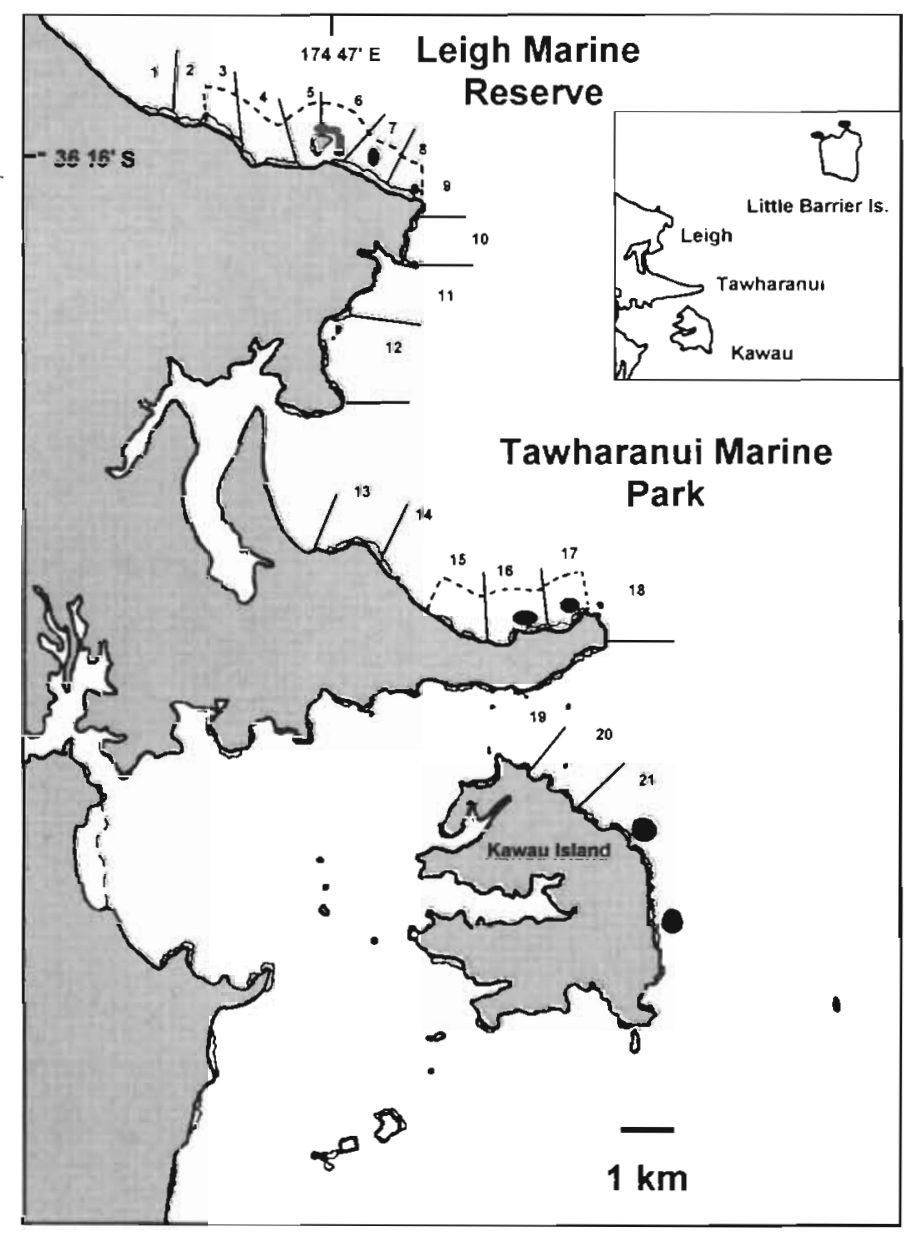

Fig. 1. Map of the study sites in northeastern New Zealand. Dashed line: Marine Reserve boundary. Numbers indicate sampling sites used in fish (1 to 18) and benthic transect (1 to 21) sampling. Shaded areas at sea are spiny lobster sampling sites 
quadrats within 26 defined $100 \mathrm{~m}^{2}$ areas. The same measurements were repeated as close as possible to 9 of these areas in 1994 and 14 of them in 1996, using the detailed maps provided by Ayling (1978). All of these areas were classified by Ayling (1978) as either kelp forest or rock-flats. Samples from 1994 and 1996 were estimated to be within a $20 \mathrm{~m}$ radius of the original 1978 areas, and were in the same depth range as Ayling's areas, as indicated on his habitat maps (Ayling 1978). In each of these areas, a total of sixteen $1 \mathrm{~m}^{2}$ quadrats were measured to determine the density and population structure of Ecklonia radiata and the density of Evechinus chloroticus. The size of E. radiata was measured as stipe length and basal stipe diameter, though only stipe length was used in subsequent productivity estimates. The size of E. chloroticus was measured as test diameter.
Primary productivity. Estimates of primary productivity were calculated based on habitat maps (Ayling 1978) and comparisons between our 1996 data and the data provided by Ayling (1978) for the density and population structure of Ecklonia radiata in kelp forest, rock-flats and shallow mixed algal habitats. Each area was classified according to the habitat type in which it fell during the 1978 survey, and productivity values ( $g$ dry weight $\mathrm{m}^{-2} \mathrm{yr}^{-1}$ ) were calculated. For each of these habitat types the primary productivity of $E$. radiata sporophytes was estimated according to Novacek (1980), who obtained size-specific productivity measures for individual plants. E. radiata populations were divided into 4 size classes: I: basal stipe diameter $<10 \mathrm{~mm}$; II: basal stipe diameter 10 to $16 \mathrm{~mm}$; III: basal stipe diameter $>16 \mathrm{~mm}$, stipe length $<700 \mathrm{~mm}$; IV: basal stipe diameter $>16 \mathrm{~mm}$, stipe length $>700 \mathrm{~mm}$.

Table 1. Change in density of kelp Ecklonia radiata and urchins Evechinus chloroticus at sites in the Leigh Marine Reserve. Means and SE for 16 quadrats. Numbering for sites listed under rock-flat and kelp forest habitat correspond to 'permanent quadrat' numbers of Ayling (1978). Bold: number of simulations (of 100) in which the 1994 or 1996 populations were found to be significantly different to populations in $1978(\alpha=0.05)$. "Change in abundance of fucoid algae similar in magnitude to that of E. radiata (Shears \& Babcock unpubl. data). Blank cells were not sampled in 1994

\begin{tabular}{|c|c|c|c|c|c|c|}
\hline \multirow{2}{*}{$\begin{array}{l}\text { Habitat type in } \\
1978\end{array}$} & \multicolumn{3}{|c|}{ E. radiata $\mathrm{m}^{-2}$} & \multicolumn{3}{|c|}{ E. chloroticus $\mathrm{m}^{-2}$} \\
\hline & 1978 & 1994 & 1996 & 1978 & 1994 & 1996 \\
\hline \multicolumn{7}{|l|}{ Rock-flats } \\
\hline 1 & $0.6(0.5)$ & & $\begin{array}{c}2(1.1) \\
11^{\circ}\end{array}$ & $5.3(1)$ & & $\begin{array}{c}1(2.6) \\
\mathbf{8 1}\end{array}$ \\
\hline 2 & $3(0.3)$ & & $\begin{array}{c}6.4(2.8) \\
99^{\circ}\end{array}$ & $2.1(0.5)$ & & $\begin{array}{c}2(2.4) \\
6\end{array}$ \\
\hline 3 & $0.5(0.3)$ & & $\begin{array}{c}8.9(1.7) \\
99^{\circ}\end{array}$ & $3.7(0.7)$ & & $\begin{array}{c}2.3(2.9) \\
40\end{array}$ \\
\hline 4 & $0.8(0.4)$ & $\begin{array}{c}1.8(1.6) \\
100\end{array}$ & $\begin{array}{c}5.6(1.9) \\
\mathbf{9 8}^{\circ}\end{array}$ & $9.6(1.5)$ & $\begin{array}{c}1.4(1.6) \\
90\end{array}$ & $\begin{array}{c}3.3(5) \\
60\end{array}$ \\
\hline 6 & 0 & $\begin{array}{c}11.3(8.6) \\
100\end{array}$ & $\begin{array}{c}13.2(4.9) \\
100\end{array}$ & $3.8(0.6)$ & $1(1.6)$ & $\begin{array}{c}0 \\
100\end{array}$ \\
\hline 7 & 0 & $\begin{array}{c}15.4(9) \\
100\end{array}$ & $\begin{array}{c}13.4(6.9) \\
100\end{array}$ & $4(0.8)$ & $0.5(1.8)$ & $\begin{array}{c}0.8 \\
100\end{array}$ \\
\hline 9 & 0 & $\begin{array}{c}24.3(15.1) \\
100\end{array}$ & $\begin{array}{c}13.3(5,6) \\
100\end{array}$ & $2.5(0.3)$ & $0.07(0.25)$ & $\begin{array}{c}0 \\
100\end{array}$ \\
\hline 1.5 & $2.9(1.4)$ & & $\begin{array}{c}11.3(2.3) \\
100\end{array}$ & $4.7(0.7)$ & & $\begin{array}{c}1.2(0.9) \\
85\end{array}$ \\
\hline 23 & 0 & & $\begin{array}{c}0.13 \\
10\end{array}$ & 3 & & $\begin{array}{c}0 \\
100\end{array}$ \\
\hline 22 & 0 & & $\begin{array}{c}19.9(6.3) \\
100\end{array}$ & $10.3(1.2)$ & $\begin{array}{c}2.7(.05) \\
100\end{array}$ & $3.4(0.6)$ \\
\hline Grand mean & $0.8(1.1)$ & $13.2(9.3)$ & $9.4(5.9)$ & $4.9(2.7)$ & 1.1(1) & $1.4(1.3)$ \\
\hline \multicolumn{7}{|l|}{ Kelp forest } \\
\hline 16 & $17.5(2)$ & $6.3(0.7)$ & $\begin{array}{c}11.1(0.9) \\
\mathbf{8 7}\end{array}$ & 0.4 & $\begin{array}{c}0 \\
100\end{array}$ & $\begin{array}{c}0 \\
100\end{array}$ \\
\hline 17 & $18.3(3.4)$ & $3.9(0.8)$ & $\begin{array}{c}12.7(1) \\
44\end{array}$ & 0.3 & $\begin{array}{c}0 \\
100\end{array}$ & $\begin{array}{c}0 \\
100\end{array}$ \\
\hline 18 & $25.5(2.1)$ & $2.4(0.7)$ & $\begin{array}{c}9.5(1.5) \\
100\end{array}$ & 0.09 & $\begin{array}{c}0 \\
100\end{array}$ & $\begin{array}{c}0 \\
100\end{array}$ \\
\hline 19 & $17.1(1.9)$ & $4.7(1.2)$ & $\begin{array}{c}9.9(0.9) \\
\mathbf{9 1}\end{array}$ & 0.7 & $\begin{array}{c}0 \\
100\end{array}$ & $\begin{array}{c}0 \\
100\end{array}$ \\
\hline Grand mean & $19.6(3.9)$ & $4.3(1.6)$ & $10.8(1.4)$ & $0.38(0.13)$ & 0 & 0 \\
\hline
\end{tabular}


Table 2. Habitat change and primary production at the Leigh reserve, 1978 to 1996 . Total area (549.16 ha) and proportional representation of subtidal rocky habitat within the reserve were estimated from Ayling (1978). Primary production estimates were based on our 1996 density and size-frequency data for Ecklonia radiata populations and published estimates of size-specific primary productivity for E. radiata (Novaczek 1980) and temperate crustose coralline algae (Littler \& Arnold 1982)

\begin{tabular}{|c|c|c|c|c|}
\hline \multirow[t]{2}{*}{ Habitat type } & \multicolumn{2}{|c|}{1978} & \multicolumn{2}{|c|}{1996} \\
\hline & $\%$ Total area & $\begin{array}{l}\text { Primary production } \\
\text { (tonnes dry wt } y \mathrm{r}^{-1} \text { ) }\end{array}$ & $\%$ Total area & $\begin{array}{l}\text { Primary production } \\
\text { (tonnes dry wt } y \mathrm{r}^{-1} \text { ) }\end{array}$ \\
\hline Shallow mixed algae & 22.2 & 67.6 & 34.7 & 105.8 \\
\hline Rock-flats & 31.4 & 6.8 & 3.2 & 0.7 \\
\hline Ecklonia radiata forest & 29.8 & 203.6 & 45.5 & 333.2 \\
\hline Total & 83.4 & 278.0 & 83.4 & 439.6 \\
\hline
\end{tabular}

Using published values for primary productivity of temperate crustose coralline algae (CCA) (Littler \& Arnold 1982), the productivity of CCA-dominated rock flats was also calculated on a per-unit area basis. These data were used to produce estimates of primary productivity for each of the main habitat types in the Leigh Marine Reserve based on their estimated projected areal extent (Table 2). The estimates of area are therefore conservative and assume a flat substratum. Data for each prescribed area in 1978 and 1996 were averaged for each habitat type and used to calculate primary productivity and change in total productivity of the main reserve habitats.

\section{RESULTS}

\section{Fish abundance}

Pagrus auratus was the most abundant demersal species, making up $54 \%$ of the demersal fish observed in video drops. At both Tawharanui and Leigh $P$. auratus were recorded at significantly greater abundances within reserves than outside (Fig. 2). Conservative estimates of the magnitude of difference between reserve and non-reserve areas were made by comparing the lower $95 \%$ confidence bounds of the reserve estimate with the upper $95 \%$ confidence bound of the non-reserve estimate. Using this method, Tawharanui and Leigh $P$. auratus ( $>$ minimum legal size) abundances were at least 5.75 and 8.70 times greater within reserves, respectively, than outside. Abundance of $P$. auratus > minimum legal size $(270 \mathrm{~mm}$ fork length) was formally analysed using a mixed model ANOVA with Area (i.e. Leigh or Tawharanui) and Status (i.e. reserve or fished areas) treated as fixed factors, and Site a nested factor within area and status. Sub-legal $P$. auratus were not analysed because they do not feed on Evechinus chloroticus (Kingett \& Choat 1981), vary seasonally regardless of reserve status (Francis 1995) and, at least in theory, are not subject to fishing mortality. Plots of the residuals against predicted or fitted values and a normal quantile-quantile, or qqplot, of the
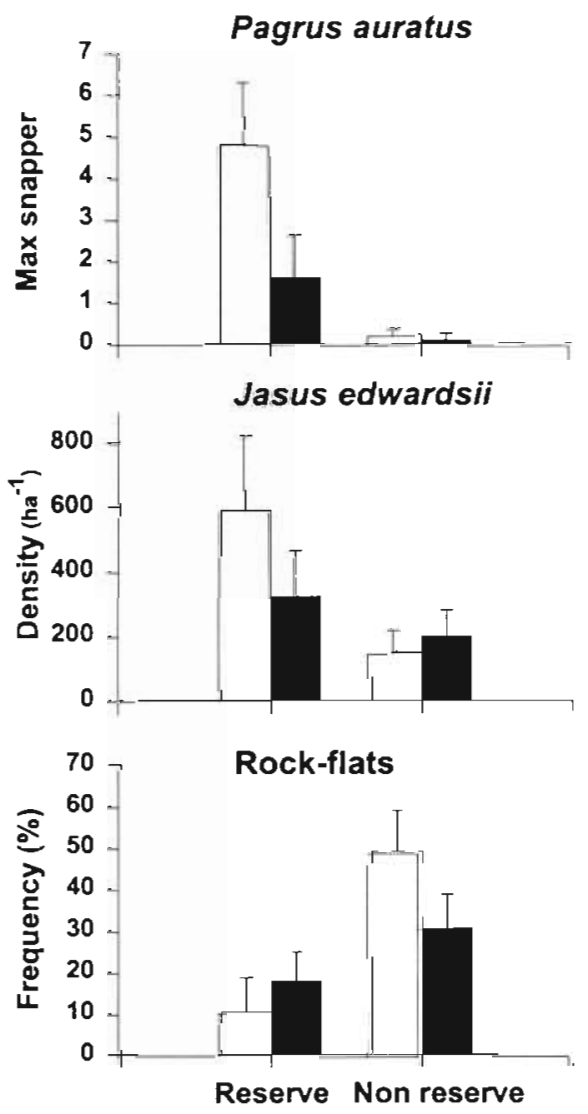

Fig. 2. Effects of no-take reserves. Predator abundance (snapper Pagrus auratus, spiny lobster Jasus edwardsii) and proportional habitat distribution inside and outside reserves. Data are means $(+95 \%$ CI). Open bars: Leigh Marine Reserve; solid bars: Tawharanui Marine Park. Max snapper data for snapper refer only to fish greater than $270 \mathrm{~mm}$ minimum legal length (Max snapper = maximum number of snapper in the camera field during one $30 \mathrm{~min}$ deployment. See text for full description of index) 
residuals indicated that the assumptions of equality of variances and normality were met. Differences with Status were statistically significant $\left(F_{1,14}=11.16, \mathrm{p}<\right.$ $0.01)$, whereas the interaction term $\left(F_{1,14}=2.58, \mathrm{p}>\right.$ $0.1)$ was not. Fish abundance did not vary significantly between areas $\left(F_{1,14}=3.01, \mathrm{p}>0.1\right)$ but among-site variability was high $\left(F_{14,54}=4.58, \mathrm{p}<0.05\right)$.

Size of Pagrus auratus inside reserves was much greater than outside them, with a mean total length in reserves of $327 \pm 9.5 \mathrm{~mm}(95 \% \mathrm{Cl})$ for $147 \mathrm{fish}$, compared with $191 \pm 7.6 \mathrm{~mm}(95 \% \mathrm{Cl})$ for $67 \mathrm{fish}$ in nonreserve areas. The size of all $P$. auratus was assessed using a 3-way ANOVA with Area, Status and Depth treated as fixed factors. Diagnostic plots of in-transformed data indicated that the model assumptions were met. No significant differences were found with Area $\left(F_{1,206}=1.1, \mathrm{p}>0.05\right)$, Depth $\left(F_{1,206}=0.5, \mathrm{p}=0.88\right)$ or interaction terms, but Status was statistically significant $\left(F_{1,206}=34.3, \mathrm{p}<0.01\right)$.

\section{Fish predation on urchins}

Analysis of gut contents of Pagrus auratus caught on coastal reefs in the area indicated that Evechinus chloroticus form a conspicuous part of its diet. Analysis of gut contents of fish from the Leigh reserve showed that 11 of 68 P. auratus as well as 3 of 6 Parapercis colias had recently fed upon $E$. chloroticus. The smallest fish found to have fed on E. chloroticus was $299 \mathrm{~mm}$ and the largest $665 \mathrm{~mm}$ fork length. Sizes of intact or partially intact tests taken of $P$. auratus were $6,8,9,15,33$, and $-60 \mathrm{~mm}$. Based on the number of urchin pyramids found, there were at least 25 other urchins in the guts of these fish. Test diameter of these urchins was estimated using regression equations relating test diameter to pyramid length (Kerrigan 1987). The average size of all urchins taken was $26.1 \pm 8.28 \mathrm{~mm}(95 \% \mathrm{CI}$ ) There was also one $5 \mathrm{~mm}$ intact test found in a P. colias.

\section{Spiny lobster abundance}

Mean densities of Jasus edwardsii were also significantly greater within the Tawharanui and Leigh reserves compared to their respective unprotected sites (Fig. 2). Abundance was examined with a mixed model ANOVA with Status, Area and Depth treated as fixed factors and Site as a random factor. Counts were $\ln (x+1)$ transformed prior to analysis and diagnostic plots indicated that the model assumptions were met. Differences in Status and Site were found to be significant $\left(F_{1,8}=25.26, \mathrm{p}<0.01\right.$ and $F_{8,56}=4.92, \mathrm{p}<0.01$ respectively) but Depth and Area were not $\left(F_{1,8}=0.37\right.$, $\mathrm{p}=0.69$ and $F_{1.8}=0.15, \mathrm{p}=0.54$ respectively). All inter- action terms that included Depth were significant due to the seasonal movement of lobsters between depth strata (see MacDiarmid 1991) and the fact that Leigh (April) and Tawharanui (October) were sampled at different times of year. The mean density for the nonreserve sites was $174 \pm 38.8(95 \% \mathrm{CI})$ lobsters ha ${ }^{-1}$ compared with $455 \pm 60.6(95 \% \mathrm{CI})$ in the protected sites.

Likewise, the mean size of lobsters was significantly larger in reserves compared to unprotected sites. Lobsters within the reserves $(\mathrm{n}=909)$ had an adjusted mean carapace length of $109.9 \pm 1.7 \mathrm{~mm}(95 \% \mathrm{CI}$ ), compared with $93.5 \pm 2.8 \mathrm{~mm}(95 \% \mathrm{Cl})$ outside the reserves $(n=348)$. A 3-way ANOVA was used to examine the effect of protection on lobster size with Status, Area and Depth treated as fixed factors. Plots of the residuals against predicted or fitted values and a normal quantile-quantile, or qqplot, of the residuals indicated that the assumptions of equality of variances and normality were met. Significant differences were found between Area $\left(F_{1,8}=17.63, \mathrm{p}<0.01\right)$, Depth $\left(F_{1,8}=2.99, \mathrm{p}<0.05\right)$ and Status $\left(F_{1,8}=34.69, \mathrm{p}<0.01\right)$. Jasus edwardsii is known to feed on Evechinus chloroticus (Andrew \& MacDiarmid 1991) and discarded urchin tests are common at lobster den sites (authors' pers. obs).

\section{Algal abundance}

The mean proportion of the substratum occupied by urchin-dominated rock-flat habitat at depths $<10 \mathrm{~m}$ differed significantly between reserve and nonreserve areas, averaging $39 \pm 7 \%(95 \% \mathrm{CI})$ outside reserves, and $13 \pm 5.9 \%(95 \% \mathrm{CI})$ inside reserves (Fig. 2). Proportional cover of rock-flat habitat was arcsine-transformed and examined using a mixed model ANOVA with Area (i.e. Leigh or Tawharanui) and Status (i.e. reserve or fished areas) treated as fixed factors, and Site (nested within area and status) as a random factor. Diagnostic plots indicated that the model assumptions were met. Differences with Status were statistically significant $\left(F_{1, t 7}=13.21, \mathrm{p}<0.01\right)$, whereas those due to the interaction term $\left(F_{1,17}=3.4, \mathrm{p}=0.08\right)$ were not. Rock-flat coverage did not differ significantly between Areas $\left(F_{1.1}=0.86, \mathrm{p}=0.37\right)$ but there was significant patchiness at the Site level $\left(F_{17,44}=\right.$ $6.05, \mathrm{p}<0.01)$.

\section{Temporal change in the density of kelp and urchins in the Leigh Marine Reserve}

By 1996, 8 of 10 areas that were initially classified as urchin-dominated rock-flats were re-classified as 
either kelp forest or shallow mixed fucoid habitat due to increased densities of Ecklonia radiata (Fig. 3, Table 1), and/or large fucoid algae (mainly Carpophyllum plumosum and C. flexuosum). Mean densities of $E$. radiata were $0.8 \pm 1.1 \mathrm{~m}^{-2} \mathrm{SE}$ in 1976 , but for the same 10 sites in 1996, mean densities increased to $9.4 \pm$ $5.9 \mathrm{~m}^{-2} \mathrm{SE}$. Four of these former rock-flat areas have been kelp forest since at least 1994 (Table 1). There have been corresponding declines in the overall abundance of Evechinus chloroticus from $4.9 \pm 2.7 \mathrm{~m}^{-2} \mathrm{SE}$ to $1.4 \pm 1.3 \mathrm{~m}^{-2} \mathrm{SE}$ at the same sites (Fig. 3, Table 1). While E. chloroticus was still found at most of the former rock-flat sites in 1994 and 1996, it was present at much lower densities than in 1978 (Table 1), and changes in density of both urchins and algae were statistically significant. Mean densities for each of the 10 sites originally classified as rock-flats were used to compile a data set that could be used to compare habitat changes between 1978 and 1996. Data for E. radiata and $E$. chloroticus were compared using a 1-way ANOVA which indicated significant differences in $E$. chloroticus density $\left(F_{1,18}=12.6, \mathrm{p}<0.01\right)$, as well as the density of $E$. radiata populations $\left(F_{1,18}=19.9, \mathrm{p}<0.01\right)$.

In addition to these comparisons using means for each site, densities from 1978 (available only as mean and SE, Ayling 1978) were compared with data from 1996 for each individual site. This was done using Monte Carlo simulations (POWER, Borenstein \& Cohen 1988), assuming normally distributed error structures based on data from the 1996 surveys, for which we had full data sets. For both Evechinus chloroticus and Ecklonia radiata 100 simulations were assessed at $\alpha<0.05$. For $E$. chloroticus the probability of a statistically significant decrease in density was $>0.8$ at 7 of the 10 sites. There was an increase in density of $E$. radiata at 8 of the 10 sites; however a decrease in density of $E$. chloroticus did not always correspond directly to an increase in $E$. radiata (e.g. quadrats 1 and 23, Table 1). None of the 4 kelp forest sites had changed community structure noticeably. Nevertheless there was a decrease in abundance of kelp at 3 of the 4 kelp forest sites (Table 1). While urchins were present at low densities in kelp forest sites in 1978 , they were completely absent from kelp forest sites during our study.

\section{Primary productivity}

Between 1978 and 1996, 80\% of rock-flat habitat sites changed to kelp forest or shallow mixed algal habitat, based on changes in density of Ecklonia radiata at prescribed areas in the Leigh Marine Reserve. Consequently we estimate that the total area of rockflats in the reserve has shrunk by an order of magnitude from 31.4 to $3.2 \%$ of the total available rocky reef

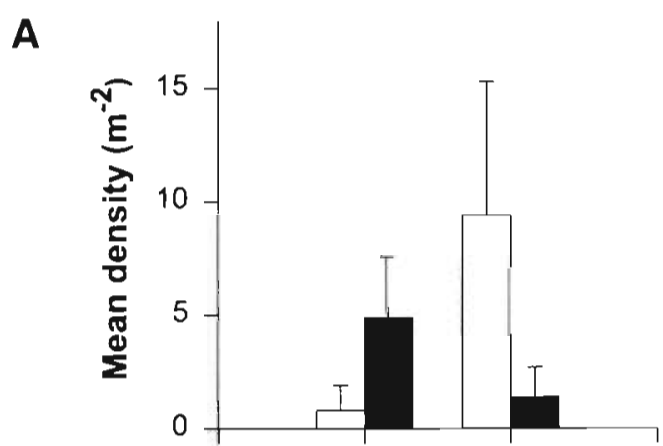

B

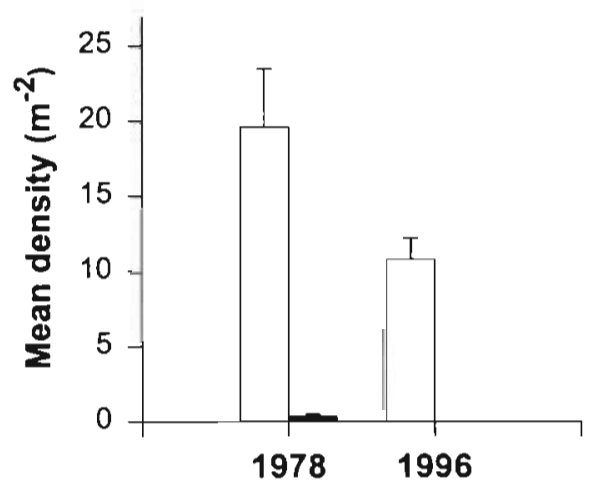

Fig, 3. Habitat change at Leigh 1978 to 1996. (A) Sites classified as urchin-grazed rock-flats in 1978, (B) sites classified as kelp forests in 1978 (Ayling 1978). Data are means (+95\% CI). Open bars: Ecklonia radiata; solid bars: Evechinus chloroticus

area. We designated the changed areas $<6 \mathrm{~m}$ as shallow mixed algae and those deeper than $6 \mathrm{~m}$ as kelp forest. Both of these habitat types expanded appreciably over the period 1978 to 1996 , at the expense of rock-flat habitat. Consequently the total estimated primary productivity of each of these habitats increased by $57 \%$ for shallow mixed algal areas and $64 \%$ for kelp forest. Overall, the total primary productivity of the rocky reef habitats we examined increased by $58 \%$ from 278 to $439 \mathrm{t}$ dry weight $\mathrm{yr}^{-1}$ (Table 2).

\section{DISCUSSION}

Greater abundances of Jasus edwardsii that we found inside reserves are consistent with earlier studies (Cole et al. 1990, MacDiarmid \& Breen 1993). We also found much larger increases in the relative abundance of Pagrus auratus than have previously been suggested (Cole et al. 1990), largely because we used a method of censusing fish that overcame some of the biases that confounded the visual survey results of Cole et al. (1990). These increases are consistent with a release from fishing pressure. 
Both Jasus edwardsii and Pagrus auratus are known to feed on the dominant grazer in New Zealand benthic reef communities, the echinoid Evechinus chloroticus. Higher E. chloroticus mortality within the Leigh reserve, relative to non-reserve areas, has been inferred by Cole \& Keuskamp (1998). Urchins transplanted to the reserve were reduced by between 10 and $90 \%$ after $6 \mathrm{~d}$, while over the same period $>80 \%$ of urchins transplanted to areas outside the reserve remained (Cole \& Keuskamp 1998). Furthermore E. chloroticus populations in marine reserves tended to have bimodal population structures (Cole \& Keuskamp 1998, Figs. $3 \&$ \&). The size of urchins we found in the guts of snapper from the Leigh reserve $(26.1 \pm$ $8.28 \mathrm{~mm}$ ) fell neatly between these 2 modes. Measurements at a number of sites in the Leigh Marine Reserve showed that densities of $E$. chloroticus have declined since 1978

The fact that proportional cover of urchin-grazed rock-flat habitats in the 2 marine reserves studied is significantly lower than in unprotected areas is likely an indirect consequence of this increase in predator abundance and reduced grazer density. Experimental removals of Evechinus chloroticus (Andrew \& Choat 1982) have shown that reduced grazer densities will lead to increased macroalgal cover, including Ecklonia radiata. In one of the reserves, E. radiata forest has expanded dramatically over a $20 \mathrm{yr}$ period into areas that were formerly urchin-grazed rock-flats. In contrast, all areas that were classified as kelp forest in 1978 remained stable as kelp forest in 1996 (Fig. 3). This was despite substantial episodic mortalities of $E$. radiata during that time (Cole \& Babcock 1996, Easton et al. 1997). We propose that higher predation upon and mortality of the urchin $E$. chloroticus inside the Leigh reserve is the cause of the observed changes in community structure within the Leigh and Tawharanui Marine Reserves.

Indirect ecological changes such as those we have observed have interesting implications because it has been suggested that Australasian kelp ecosystems have always lacked 'keystone' predators (Andrew \& Choat 1982, Andrew \& MacDiarmid 1991). As a consequence of this conclusion it has been hypothesised that Australasian reefs have been dominated by urchins, and algae there have developed heavier chemical defenses than their northern hemisphere counterparts (Steinberg et al. 1995). Further evaluation of these ideas is required in light of our data which suggest that predation can play a key regulatory role in New Zealand kelp ecosystems. The protection and reintroduction of sea otters in parts of their former range in the northeastern Pacific (Estes \& Palmisano 1974, Duggins 1980 ) present a situation analogous to the one we have described in northeastern New Zealand. While the shift in community structure we have observed is not as pronounced as reported in southeastern Alaska, it is similar to the situation found in the western Aleutians (Estes \& Duggins 1995), where high rates of urchin recruitment appear to reduce the rate and degree of habitat transition.

Our results also suggest how no-take marine reserves can change benchmarks for environmental and fisheries management. The recovery of kelp populations subsequent to protection indicates that fishing activities on New Zealand's northeastern coast have had ecological impacts far beyond the target species. These effects, though indirect, are just as striking as those caused by fishing practices such as trawling, which remove or destroy conspicuous components of fished habitats (Rothschild et al. 1994, Dayton et al. 1995, Watling \& Norse 1998). Perhaps more importantly in the case of kelp forests, these conspicuous components are also major primary producers (Mann 1973), whose contribution to detrital food webs is central to ecosystem function and diversity (Duggins 1980). Using habitat maps and surveys of the Leigh reserve made in 1978 (Ayling 1978) and 1996, we have estimated that macroalgal primary productivity is approximately $58 \%$ greater within the Leigh reserve than it was $20 \mathrm{yr}$ ago. The corollary of this is that benthic primary productivity in areas outside of reserves is much lower than it was prior to intensive fishing. It is not yet clear how such fishing-mediated reductions in primary productivity flow through to different trophic levels, but data from kelp forests in the northeast Pacific indicate that their contribution could be substantial (Duggins et al. 1984). Kelp forests in northeastern New Zealand are known to have far higher rates of secondary production than do rock-flat habitats (Taylor 1998), supporting the suggestion that these effects are likely to be broadly felt throughout the ecosystem.

These observations indicate that the efficient management of coastal fisheries can no longer ignore the consequences of fishing on the wider ecosystem, and attempts are now being made to understand benthic ecosystems in terms of multi-species fisheries models (McClanahan \& Sala 1997). No-take marine reserves represent a large scale ecological tool that can play an important part in the development of such models. Unfished areas provide a way of assessing ecosystem function and avoiding the 'sliding baseline' phenomenon, in which expectations of what is natural are reduced because many of the original components of the system are reduced or absent (Dayton et al. 1998) It has been suggested that the results of ecological studies conducted in marine reserves cannot be extrapolated to other, fished, areas (Cole \& Keuskamp 1998). We suggest that a more useful perspective is not to extrapolate and use ideas based on exploited areas 
as the basis for understanding the fundamentals of benthic ecosystem function. By establishing knowledge of ecosystem function based on both protected and exploited areas, ecology will be more likely to contribute to the judicious use of marine ecosystems and the preservation of their many attributes.

Acknowledgements. Thanks to G. Branch, R. Creese, J. Estes, D. Schiel, P. Steinberg, M. Tegner and 3 anonymous reviewers for comments on the manuscript. M. Birch, B. Doak, S. Lyons and L. Munro assisted with data collection. This work was funded in part by the New Zealand Dept. of Conservation, Investigation Nos. 1946, 1535 and 2174.

\section{LITERATURE CITED}

Agardy MT (1994) Advances in marine conservation: the role of marine protected areas. Trends Ecol Evol 9:267

Allison GW, Lubchenco J, Carr MH (1998) Marine reserves are necessary but not sufficient for marine conservation. Ecol A.ppl 8:579-592

Andrew NL, Choat JH (1982) The influence of predation and conspecific adults on the abundance of juvenile Evechinus chloroticus (Echinoidea: Echinodermata). Oecologia 54: 80-87

Andrew NL. MacDiarmid AB (1991) Inter-relations between sea urchins and spiny lobsters in northeastern New Zealand. Mar Ecol Prog Ser 70:211-222

Ayling AM (1978) Cape Rodney to Okakari Point Marine Reserve Survey. Leigh Marine Laboratory Bulletin 1, Leigh Marine Laboratory, Auckland

Bennett BA, Attwood CG (1991) Evidence for recovery of a surf-zone fish assemblage following the establishment of a marine reserve on the southern coast of South Africa. Mar Ecol Prog Ser 75:173-181

Borenstein M, Cohen J (1988) Statistical power analysis: a computer program. Lawrence Erlbaum Ass Inc, Hillsdale, NJ

Botsford LW, Castilla JC, Peterson CH (1997) The management of marine ecosystems. Science 277:509-515

Chapman ARO, Johnson CR (1990) Disturbance and organization of macroalgal assemblages in the northwest Atlantic. Hydrobiologia 192:77-121

Choat JH, Schiel DR (1982) Patterns of distribution and abundance of large brown algae and invertebrate herbivores in subtidal regions of northern New Zealand. J Exp Mar Biol Ecol 60:129-162

Cole RG (1994) Abundance, size structure, and diver-oriented behaviour of three large benthic carnivorous fishes in a marine reserve in northeastern New Zealand. Biol Conserv 70:93-99

Cole RG, Babcock RC (1996) Mass mortality of a dominant kelp (Laminariales) at Goat Island, north-eastern New Zealand. Mar Freshw Res 47:907-911

Cole RG, Keuskamp D (1998) Indirect effects of protection from exploitation: patterns from populations of Evechinus chloroticus (Echinoidea) in northeastern New Zealand. Mar Ecol Prog Ser 173:215-226

Cole RG, Ayling AM, Creese RG (1990) Effects of marine reserve protection at Goat Island, northern New Zealand. NZ J Mar Freshw Res 24:197-210

Creese RG, Jeffs (1993) Biological research in New Zealand marine reserves. In: Battershill $C N$, Schiel DR, Jones GP, Creese RG, MacDiarmid AB (eds) Proceedings of the 2nd International Temperate Reef Symposium. NIWA Marine, Wellington, p 15-45

Dayton PK, Thrush SF, Agardy MT, Hofman RJ (1995) Environmental effects of marine fishing. Aquat Conserv: Mar Freshw Ecosyst 5:205-232

Dayton PK Tegner MJ, Edwards PB, Riser KL (1998) Sliding baselines, ghosts, and reduced expectations in kelp forest communities. Ecol Appl 8:309-322

Duggins DO (1980) Kelp beds and sea otters: an experimental approach. Ecology 6:447-453

Duggins DO, Simenstad SA, Estes JA (1984) Magnification of secondary production by kelp detritus in coastal marine ecosystems. Science 245:170-173

Duran LR, Castilla JC (1989) Variation and persistence of the middle rocky intertidal community of central Chile, with and without human harvesting. Mar Biol 103:555-562

Easton LM, Lewis GD, Pearson MN (1997) Virus-like particles associated with dieback symptoms in the brown alga Ecklonia radiata. Dis Aquat Org 30:217-222

Elner RW, Vadas RL (1990) Inference in ecology: the sea urchin phenomenon in the northwestern Atlantic. Am Nat 136: $108-125$

Estes JA, Duggins DO (1995) Sea otters and kelp forests in Alaska: generality and variation in a community ecological paradigm. Ecol Monogr 65:75-100

Estes JA, Palmisano JF (1974) Sea otters: their role in structuring nearshore communities. Science 185:1058-1060

Estes J, Tinker MT, Williams TM, Doak DF (1998) Killer whale predation on sea otters linking oceanic and nearshore systems. Science 282:473-476

Francis MP (1995) Spatial and seasonal variation in the abundance of juvenile snapper (Pagrus auratus) in the northwestern Hauraki Gulf. NZ J Mar Freshw Res 29: $565-579$

Kerrigan B (1987) Abundance patterns of intertidal and subtidal populations of Evechinus chloroticus. MSc thesis, University of Auckland

Kingett PD, Choat JH (1981) Analysis of density and distribution patterns in Chrysophrys auratus (Pisces: Sparidae) within a reef environment: an experimental approach. Mar Ecol Prog Ser 5:283-290

Littler MM, Arnold KE (1982) Primary productivity of marine macroalgal functional-form groups from southwestern North America. J Phycol 18:307-311

MacDiarmid AB (1991) Seasonal changes in depth distribution, sex ratio and size-frequency of spiny lobster Jasus edwardsii on a coastal reef in northern New Zealand. Mar Ecol Prog Ser 70:129-141

MacDiarmid AB, Breen PA (1993) Spiny lobster population change in a marine reserve. In: Battershill CN, Schiel DR, Jones GP, Creese RG, MacDiarmid AB (eds) Proceedings of the 2nd International Temperate Reef Symposium. NIWA Marine, Wellington, p 47-56

Mann KH (1973) Seaweeds: their productivity and strategy for growth. Science 182:975-981

McClanahan TR (1997) Primary succession of coral-reef algae: differing patterns on fished versus unfished reefs. J Exp Mar Biol Ecol 218:77-102

McClanahan TR, Sala E (1997) A. Mediterranean rocky-bottom ecosystem fisheries model. Ecol Model 104:145-164

Millar RB, Willis TJ (1999) Estimating the relative density of snapper in and around a marine reserve using a log-linear mixed effects model. Aust N Z J Stat 41:383-394

Novaczek 1 (1980) The development and phenology of Ecklonia radiata. PhD thesis, University of Auckland 
Pauly D, Christensen V, Dalsgaard, J, Froese R, Torres F (1998) Fishing down marine food webs. Science 279: $860-863$

Rakitin A, Kramer DL (1996) Effect of a marine reserve on the distribution of coral reef fishes in Barbados. Mar Ecol Prog Ser 131:97-113

Rothschild BJ, Ault JS, Goulletquer P, Heral M (1994) Decline of the Chesapeake Bay oyster population: a century of habitat destruction and overfishing. Mar Ecol Prog Ser 111:29-39

Russ GR, Alcala AC (1996) Marine reserves: rates and patterns of recovery and decline of large predatory fish. Ecol Appl 6:947-961

Sala E, Boudouresque CF, Harmelin-Vivien M (1998) Fishing, trophic cascades, and the structure of algal assemblages: evaluation of an old but untested paradigm. Oikos 82: $425-439$

Schiel DR (1982) Selective feeding by the echinoid Evechinus

Editorial responsibility: Otto Kinne (Editor),

Oldendorf/Luhe, Germany chloroticus, and the removal of plants from subtidal algal stands in northern New Zealand. Oecologia 54:379-388 Schiel DR (1990) Macroalgal assemblages in New Zealand structure, interactions and demography. Hydrobiologia 192:59-76

Steinberg PD, Estes JA, Winter FC (1995) Evolutionary consequences of food chain length in kelp forest communities Proc Natl Acad Sci USA 92:8145-8148

Taylor RB (1998) Density, biomass and productivity of animals in four subtidal rocky reef habitats: the importance of small mobile invertebrates. Mar Ecol Prog Ser 172:37-51

Watling L, Norse EA (1998) Disturbance of the seabed by mobile fishing gear: a comparison to forest clearcutting Conserv Biol 12:1180-1197

Willis TJ, Millar RB, Babcock RC (unpublished) Detection of spatial variability in relative density of fishes: comparison of visual census, angling, and baited unterwater video Mar Ecol Prog Ser

Submitted: March 3, 1999; Accepted: June 16, 1999

Proofs received from author(s): November 9, 1999 